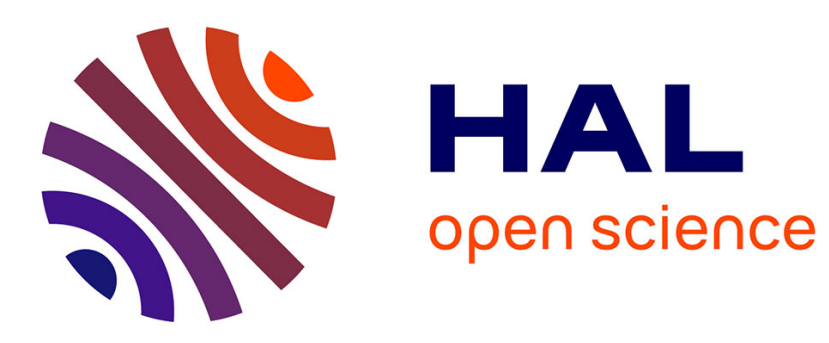

\title{
Water solubility in silica and quartzofeldspathic melts
}

François Holtz, Jacques Roux, Harald Behrens, Michel Pichavant

\section{To cite this version:}

François Holtz, Jacques Roux, Harald Behrens, Michel Pichavant. Water solubility in silica and quartzofeldspathic melts. American Mineralogist, 2000, 85, pp.682-686. hal-00077547

\section{HAL Id: hal-00077547 https://hal-insu.archives-ouvertes.fr/hal-00077547}

Submitted on 31 May 2006

HAL is a multi-disciplinary open access archive for the deposit and dissemination of scientific research documents, whether they are published or not. The documents may come from teaching and research institutions in France or abroad, or from public or private research centers.
L'archive ouverte pluridisciplinaire $\mathbf{H A L}$, est destinée au dépôt et à la diffusion de documents scientifiques de niveau recherche, publiés ou non, émanant des établissements d'enseignement et de recherche français ou étrangers, des laboratoires publics ou privés. 


\title{
Water solubility in silica and quartzofeldspathic melts
}

\section{Francois Holtz, ${ }^{1,2, *}$ Jacques Roux, ${ }^{1}$ Harald Behrens, ${ }^{2}$ And Michel Pichavant ${ }^{1}$}

\author{
${ }^{1}$ Centre de Recherches sur la Synthèse et la Chimie des Minéraux, CRSCM-CNRS, 1A rue de la Férollerie, 45071 Orléans, France \\ ${ }^{2}$ Institut für Mineralogie, Universität Hannover, Welfengarten 1, 30167 Hannover, Germany
}

\begin{abstract}
Water solubility in silica melts was determined at $100-600 \mathrm{MPa}, 1200-1350{ }^{\circ} \mathrm{C}$, and at each temperature $(T)$ was found to increase with pressure $(P)$. At $P \leq 250 \mathrm{MPa}$, the effect of $T$ on water solubility in silica melts is small and within analytical precision $\left( \pm 0.15 \mathrm{wt} \% \mathrm{H}_{2} \mathrm{O}\right)$. A positive correlation with $T$ was observed at $400 \mathrm{MPa}$. Increasing solubility of water with increasing $T$ was observed when large amounts of water are dissolved in silica and quartzofeldspathic melts (i.e., when molecular water is the dominant species in the glasses at room temperature), as already observed for feldspar melts. Change in water solubility (expressed in mol\%) with decreasing $\mathrm{SiO}_{2}$ content of the melt is nonlinear along the silica-albite join. In the compositional range $A b_{100}$ to $A b_{25}$ (100 to 25 $\mathrm{mol} \%$ albite, respectively, compositions calculated on an eight-oxygen basis), the solubility of water at $200 \mathrm{MPa}$ decreases only slightly with decreasing $\mathrm{Ab}$ content $\left(-0.1 \pm 0.01 \mathrm{~mol} \% \mathrm{H}_{2} \mathrm{O}\right.$ per mol\% albite). However, at Ab contents less than $25 \mathrm{~mol} \%$, water solubility decreases sharply with increasing Qz content. Similar behavior was observed at $500 \mathrm{MPa}$. These results suggest that two different incorporation mechanisms of water in quartzofeldspathic melts must be considered: one corresponding to an $\mathrm{NaAlSi}_{3} \mathrm{O}_{8}-\mathrm{H}_{2} \mathrm{O}$ mechanism, the other to an $\mathrm{SiO}_{2}-\mathrm{H}_{2} \mathrm{O}$ mechanism.
\end{abstract}

\section{INTRODUCTION}

Data on water solubility and speciation of water in silica melts are needed to determine the incorporation mechanisms of water in more complex, multicomponent aluminosilicate melts. Although numerous studies have focused on water incorporation mechanisms in aluminosilicate melts of feldspar stoichiometry, very few data are available for the join silicaalbite. For albite melts, the NMR results of Kohn et al. (1989) suggested that hydroxyl groups are not bonded to Si. Sykes and Kubicki (1993) suggested that only minor $\mathrm{Si}-(\mathrm{OH})$ bonds exist in albite. Although the interpretations of Kohn et al. (1989) and Sykes and Kubicki (1993) are still under debate, significant differences are likely between the incorporation mechanisms of water in albite melts, where $\mathrm{Na}$ is involved in the dissolution process, and in silica melts, where water species can only be bonded to Si (e.g., Kohn et al. 1989; Pichavant et al. 1992). Because the incorporation mechanisms of water in pure silica glasses and melts are not fully understood, it is unclear whether models developed for feldspathic melts apply to more silica-rich compositions (e.g., rhyolitic melts).

Experimental data for the $\mathrm{SiO}_{2}-\mathrm{H}_{2} \mathrm{O}$ system constrain the $\mathrm{H}_{2} \mathrm{O}$-saturated and $\mathrm{H}_{2} \mathrm{O}$-undersaturated quartz solidus and the solubility of $\mathrm{SiO}_{2}$ in the fluid phase coexisting with melt or crystals (Ostrovskiy et al. 1959; Kennedy et al. 1962; Stewart

*E-mail: f.holtz@mineralogie.uni-hannover.de
1967; Boettcher 1984). Water solubility data are only available for the pressure $(P)$ and temperature $(T)$ conditions of the $\mathrm{SiO}_{2}-$ and vapor-saturated solidus (Kennedy et al. 1962). Thus, there are no data for hyperliquidus conditions that permit determination of the individual effects of $P$ and $T$ on water solubility. In this study, the solubility of water has been determined for silica melts at $100-600 \mathrm{MPa}, 1200-1350{ }^{\circ} \mathrm{C}$, and for albite $(\mathrm{Ab})$ and quartz-albite (Qz-Ab) melts at 200 and $500 \mathrm{MPa}, 1100-1300^{\circ} \mathrm{C}$. The data for feldspathic melts constrain the solubility mechanisms of water in intermediate silica-feldspar melt compositions. Numerous studies have been performed to determine water solubilities in albite melts (see review in Behrens 1995; Romano et al. 1996), but little information is available for Qz-Ab melts. The results of Oxtoby and Hamilton (1978a, 1978b) showed that water solubility is significantly higher in quartzofeldspathic melts than in silica melts. However, their data are only qualitative, because water solubility was underestimated at $P>200$ to $300 \mathrm{MPa}$ due to problems inherent in the analytical technique used to determine the water contents of the glasses (see Silver and Stolper 1989 and Holtz et al. 1995 for further details).

\section{EXPERIMENTAL METHODS AND ANALYTICAL TECHNIQUES}

\section{Apparatus and procedures}

All experiments to determine the solubility of water in silica melts (Table 1) were conducted at Orléans (CRSCM-CNRS). Experiments with $\mathrm{Ab}$ and $\mathrm{Qz}-\mathrm{Ab}$ compositions were performed 
both at Orléans $\left(1300^{\circ} \mathrm{C}\right)$ and Hannover $\left(1200\right.$ and $\left.1100{ }^{\circ} \mathrm{C}\right)$. At Orléans, experiments were conducted in two internally heated pressure vessels, oriented vertically and equipped with (kanthal A1 and Pt wound) furnaces as described by Roux et al. (1994). The furnaces permited samples to be reacted at temperatures as high as $1400{ }^{\circ} \mathrm{C}$ for durations up to several days. Thermal gradients along the samples (enclosed in capsules $\leq 2$ $\mathrm{cm}$ in length) were always less than $10^{\circ} \mathrm{C}$. After switching off furnace power, cooling rates were approximately $300{ }^{\circ} \mathrm{C} / \mathrm{min}$ between the experimental temperature and $900{ }^{\circ} \mathrm{C}$ and 180 to $150{ }^{\circ} \mathrm{C} /$ min between 900 and $500{ }^{\circ} \mathrm{C}$. Pressures were measured with transducers, calibrated against a $700 \mathrm{MPa}$ Bourdon-tube gauge (estimated uncertainty: $\pm 2 \mathrm{MPa}$ ). Temperatures were determined using four $\mathrm{Pt}_{94} \mathrm{Rh}_{6}-\mathrm{Pt}_{70} \mathrm{Rh}_{30}$ unsheathed thermocouples (estimated uncertainty: $\pm 10^{\circ} \mathrm{C}$ ). At Hannover, the experiments were conducted in an internally heated pressure vessel oriented vertically and equipped with dual-zone Mowound furnaces (estimated uncertainty for pressure: $\pm 0.1 \%$ of the measured pressure, see Becker et al. 1998 for further details). Thermal gradients along the samples, measured with four chromel-alumel type $\mathrm{K}$ thermocouples (estimated uncertainty: $\pm 5^{\circ} \mathrm{C}$ ), were less than $10^{\circ} \mathrm{C}$. Cooling rates were approximately $150{ }^{\circ} \mathrm{C} / \mathrm{min}$ from experimental temperature down to $500{ }^{\circ} \mathrm{C}$. Cooling from $500{ }^{\circ} \mathrm{C}$ to room temperature took approximately 13 to $15 \mathrm{~min}$ (for the pressure vessels used at both locations). The starting materials for silica glasses-40 to $200 \mathrm{mg}$ of bubble-free blocks of dry quartzil glass containing a few ppm water and doubly distilled water-were loaded into Pt capsules. Water was added in excess of the expected water solubility

TABLE 1. Experimental conditions for synthesis of hydrous glasses and measured $\mathrm{H}_{2} \mathrm{O}$ contents in silica glasses

\begin{tabular}{|c|c|c|c|c|c|c|c|}
\hline $\begin{array}{l}\overline{\text { Caps. }} \\
\text { no. }\end{array}$ & $\begin{array}{c}P \\
\text { (bars) }\end{array}$ & $\begin{array}{c}T \\
\left({ }^{\circ} \mathrm{C}\right)\end{array}$ & $\begin{array}{c}\mathrm{H}_{2} \mathrm{O} \text { added } \\
\text { (wt\%) }\end{array}$ & $\begin{array}{l}\text { Exp. } \\
\text { duration } \\
\text { (hours) }\end{array}$ & $\begin{array}{l}\text { Obser- } \\
\text { vations }\end{array}$ & $\begin{array}{c}\mathrm{H}_{2} \mathrm{O} \\
(\mathrm{KFT})\end{array}$ & $\begin{array}{c}\mathrm{H}_{2} \mathrm{O} \text { sol. } \\
\left(\mathrm{wt} \% \mathrm{H}_{2} \mathrm{O}\right)\end{array}$ \\
\hline 1 & 1010 & 1350 & 5.1 & 74 & C & 2.42 & 2.48 \\
\hline 2 & 1010 & 1350 & 8.1 & 74 & C & 2.35 & \\
\hline 3 & 1550 & 1200 & 5.5 & 92 & C & 2.98 & 3.08 \\
\hline 4 & 1500 & 1275 & 6.8 & 60 & C & 2.87 & 3.02 \\
\hline 5 & 1500 & 1275 & 14.8 & 60 & C & 2.98 & \\
\hline 6 & 1570 & 1300 & 6.0 & 47 & C & 3.03 & 3.13 \\
\hline 7 & 1550 & 1350 & 6.1 & 66 & C & 3.18 & 3.28 \\
\hline 17 & 2030 & 1200 & 6.2 & 91 & C & 3.73 & 3.83 \\
\hline 18 & 2010 & 1300 & 6.3 & 74 & C & 3.73 & 3.83 \\
\hline 8 & 2520 & 1200 & 8.8 & 95 & QB & 4.06 & 4.25 \\
\hline 9 & 2520 & 1200 & 8.5 & 95 & QB & 4.24 & \\
\hline 10 & 2500 & 1280 & 6.2 & 62 & C & 4.02 & 4.12 \\
\hline 11 & 2520 & 1350 & 7.0 & 90 & $\mathrm{C} / \mathrm{QB}$ & $4.35 / 4.28$ & 4.41 \\
\hline 12 & 4030 & 1200 & 8.0 & 93 & QB & 5.18 & 5.32 \\
\hline 13 & 4030 & 1200 & 10.0 & 93 & QB & 5.26 & \\
\hline 14 & 4100 & 1350 & 7.5 & 59 & QB & 5.66 & 5.78 \\
\hline 15 & 4100 & 1350 & 12.0 & 59 & QB & 5.71 & \\
\hline 16 & 6000 & 1200 & 11.0 & 94 & QB & 7.95 & 8.05 \\
\hline
\end{tabular}

(see Table 1). In some experiments, different fractions of water (all above the expected saturation value) were added to test for the effect of dissolved silica on the water content of the glass. Durations of experiments ranged from 47 to 95 hours (Table 1). The size of the samples and the experimental conditions ( $P$, $T$, duration) were chosen so that diffusion of water would be sufficiently rapid to achieve a homogeneous distribution of water in the quenched glass samples (see discussion in Holtz et al. 1995). The microprobe analyses of the starting $\mathrm{Ab}$ and Qz-Ab anhydrous glasses are given in Holtz et al. (1999). The normative proportions of $\mathrm{Qz}$ and $\mathrm{Ab}\left(\mathrm{wt} \% \mathrm{SiO}_{2}\right.$ and wt\% $\mathrm{NaAlSi}{ }_{3} \mathrm{O}_{8}$, respectively) in the glasses are: $\mathrm{Qz}_{0}: \mathrm{Ab}_{100}$, $\mathrm{Qz}_{25}: \mathrm{Ab}_{75}, \mathrm{Qz}_{50}: \mathrm{Ab}_{50}, \mathrm{Qz}_{75}: \mathrm{Ab}_{25}$. If the intermediate compositions are expressed as mol\% $\mathrm{Si}_{4} \mathrm{O}_{8}$ and $\mathrm{NaAlSi}_{3} \mathrm{O}_{8}$, the mole proportions are $\mathrm{Qz}_{26} \mathrm{Ab}_{74}, \mathrm{Qz}_{52} \mathrm{Ab}_{48}$, and $\mathrm{Qz}_{76} \mathrm{Ab}_{24}$, respectively.

\section{Determination of water contents}

The water contents of the hydrous glasses were determined by Karl Fischer titration (KFT). In this procedure (1) the samples are heated progressively up to 1300 or $1350{ }^{\circ} \mathrm{C}$ (for quartzofeldspathic and silica glasses, respectively) in an induction furnace, and (2) the liberated water species are transported by a dry argon stream to a titration cell. The analytical precision increases with increasing amount of sample and is better than $\pm 0.15 \mathrm{wt} \% \mathrm{H}_{2} \mathrm{O}$ (the amount of sample used ranged from 10 to $20 \mathrm{mg}$; for further details on uncertainties, see Behrens 1995; Holtz et al. 1995). Bubble-free glasses were coarsely crushed prior to extraction of water. This was necessary because the sudden release of water in silica-rich glasses can cause them to decrepitate. This lowers measured water contents, because fragments of glass are spewn out of the hot zone of the induction furnace. For bubble-bearing samples, single glass blocks were used to limit loss of water from the quench bubbles during crushing. Further details of this analytical procedure are given by Behrens (1995) and Holtz et al. (1995). Spectroscopic analyses of glasses following KFT showed that the samples still contain $0.10 \pm 0.05 \mathrm{wt} \% \mathrm{H}_{2} \mathrm{O}$, regardless of the initial water content of the glass or the anhydrous composition (Behrens 1995). Thus, all the measured water contents obtained in this study were corrected by adding 0.1 wt $\% \mathrm{H}_{2} \mathrm{O}$. The water solubility data given in Table 1 are average values of all water contents of samples synthesized at the same $P$ and $T$.

\section{RESULTS}

Run products of $\mathrm{SiO}_{2}-\mathrm{H}_{2} \mathrm{O}$ samples reacted at $P \leq 250 \mathrm{MPa}$ were clear, bubble-free glasses, whereas those from samples reacted at $P>250 \mathrm{MPa}$ were cloudy, bubble-bearing glasses. In each quenched sample, "free" water was present. In one case (experiment 11, Table 1), the glass was bubble-free at one end of the sample and contained bubbles at the other end. In this experiment, a piece of glass approximately $1 \mathrm{~cm}$ long was used, and after reaction it clearly showed that the bubbles were formed during the quench. The explanation for this is as follows. After switching off furnace power, the cooling rates were not uniform in the vertically oriented vessel, and the lower part of the sample cooled faster than the upper part as a result of thermal convection (the temperature gradient was recorded by four ther- 
mocouples). Thus, quenching is faster at the bottom than at the top of a vertically oriented capsule, and the relatively slow quench at the top of the $1 \mathrm{~cm}$ long sample explains the presence of bubbles in the upper part of the reacted glass.

The measured water contents of the hydrous silica glasses are given in Table 1, and the effects of $P$ and $T$ on water solubility in these melts are shown in Figure 1. The water solubilities determined in $\mathrm{Ab}$ and $\mathrm{Qz}-\mathrm{Ab}$ melts, as well as in one feldspar melt $\left(\mathrm{Ab}_{50} \mathrm{Or}_{50}\right)$, are given in Table 2. For these compositions, quench bubbles were not observed in the run products. Table 2 also contains five water solubility values determined at $1100{ }^{\circ} \mathrm{C}$ in previous studies.

No significant variation of water content was observed in $\mathrm{SiO}_{2}-\mathrm{H}_{2} \mathrm{O}$ glasses reacted at the same $P-T$ conditions (Table 1 ), and no variation of water content was observed (within analytical error) with changing amount of added water (experiments 4-5 and 12-13, Table 1). The good reproducibility of the experiments, together with the presence of water in each capsule after the experiment and the homogeneous distribution of water within the samples (determined by micro-Raman and micro-infrared spectroscopy), suggest that equilibrium was attained and that the samples were saturated with water. Reversal experiments and duplicate experiments with different run durations were not carried out in this study but were performed by Behrens (1995) with albite glasses reacted at 1100 ${ }^{\circ} \mathrm{C}, 200$ and $500 \mathrm{MPa}$. The water contents of the glasses obtained using (1) dry starting material and (2) prehydrated glasses (with initial water contents higher than the expected water solubility) were identical within analytical uncertainty $( \pm 0.11$ at $200 \mathrm{MPa}$ and \pm 0.14 at $500 \mathrm{MPa}$ ). Using glass pieces of the same size as those used in this study, Behrens (1995) showed that the water contents of glasses were identical within analytical uncertainty after run durations of 20 and 100 hours (1100 $\left.{ }^{\circ} \mathrm{C}\right)$. Because all of the experimental temperatures in this study were above $1100{ }^{\circ} \mathrm{C}$, and run durations were greater than 45 hours (Table 1), we assume that melt-fluid equilibrium was achieved in each of our experiments.

KFT analyses of a bubble-free and a bubble-bearing fragment from the same sample (experiment 11) agree within estimated analytical error, implying that the presence of bubbles

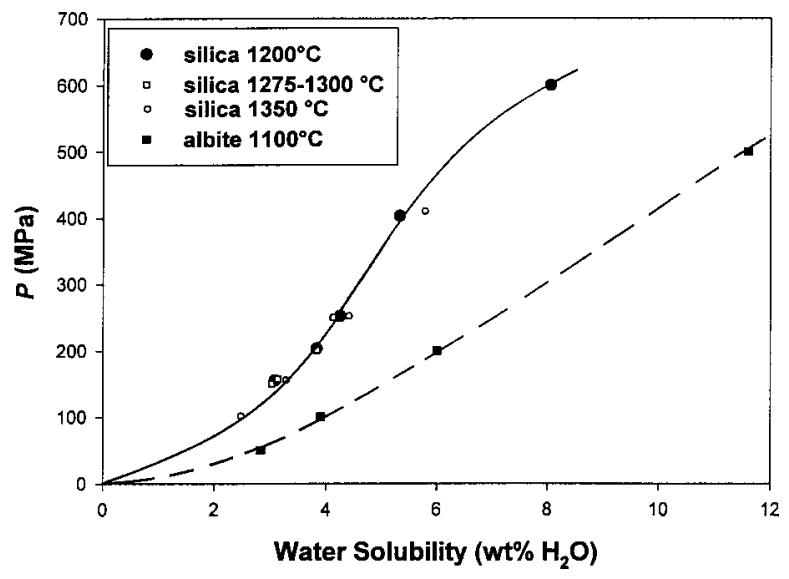

FIGURE 1. Water solubility in silica and albite melts as a function of pressure. Analytical data are presented in Table 1. The continuous curve represents water solubility in silica melts at $1200{ }^{\circ} \mathrm{C}$. A water solubility curve for albite melts at $1100^{\circ} \mathrm{C}$ (dashed line, Behrens 1995) is shown for comparison.

has no measurable effect on the determination of water solubility. The micro-Raman spectra of the bubble-free and bubblebearing parts of the glass obtained in experiment $11(P=252$ $\mathrm{MPa})$ were similar in the frequency range $3000-3700 \mathrm{~cm}^{-1}$, indicating that only minor amounts of water are contained in the bubbles. For glasses with higher water contents (samples synthesized at $P>400 \mathrm{MPa}$ ), micro-Raman spectra suggest the presence of free water. However, because single glass blocks were used to determine the water contents of bubble-bearing glasses, loss of exsolved water was minimal, and effects on water solubility determinations are probably negligibly small.

The water solubility experiments performed with $\mathrm{Ab}$ and Qz-Ab melts were not duplicated. However, the data in Table 2 are internally consistent, and indicate that water solubility is systematically slightly lower at $1300{ }^{\circ} \mathrm{C}$ than at $1200{ }^{\circ} \mathrm{C}$, as expected for quartzofeldspathic and alkali feldspar melts at 200 MPa (Holtz et al. 1992; Behrens et al. Unpublished manuscript).

TABLE 2. Water solubility data for feldspathic and quartzofeldspathic melts

\begin{tabular}{|c|c|c|c|c|c|c|}
\hline Composition & $\begin{array}{c}P \\
\text { (bars) }\end{array}$ & $\begin{array}{c}T \\
\left({ }^{\circ} \mathrm{C}\right)\end{array}$ & $\begin{array}{c}\mathrm{H}_{2} \mathrm{O} \text { added } \\
(w t \%)\end{array}$ & $\begin{array}{c}\text { Exp. } \\
\text { duration } \\
\text { (hours) }\end{array}$ & $\begin{array}{c}\mathrm{H}_{2} \mathrm{O} \text { sol. } \\
\left(\mathrm{wt} \% \mathrm{H}_{2} \mathrm{O}\right)\end{array}$ & $\begin{array}{c}\text { Source of } \\
\text { data }\end{array}$ \\
\hline $\mathrm{Ab}_{100}$ & 2030 & 1200 & 10.1 & 91 & 5.93 & this study \\
\hline $\mathrm{Ab}_{100}$ & 2010 & 1300 & 10.3 & 74 & 5.62 & this study \\
\hline $\mathrm{Ab}_{75} \mathrm{Qz}_{25}$ & 2030 & 1200 & 9.9 & 91 & 5.57 & this study \\
\hline $\mathrm{Ab}_{75} \mathrm{Qz}_{25}$ & 2010 & 1300 & 10.1 & 74 & 5.31 & this study \\
\hline $\mathrm{Ab}_{50} \mathrm{Qz}_{50}$ & 2030 & 1200 & 9.8 & 91 & 5.37 & this study \\
\hline $\mathrm{Ab}_{50} \mathrm{Qz}_{50}$ & 2010 & 1300 & 10.5 & 74 & 5.10 & this study \\
\hline $\mathrm{Ab}_{25} \mathrm{Qz}_{75}$ & 2030 & 1200 & 10.3 & 91 & 4.94 & this study \\
\hline $\mathrm{Ab}_{25} \mathrm{Qz}_{75}$ & 2010 & 1300 & 9.6 & 74 & 4.73 & this study \\
\hline $\mathrm{Ab}_{50} \mathrm{Or}_{50}$ & 2000 & 1100 & 9.2 to 10.0 & 72 to 84 & $5.68^{*}$ & Romano et al. (1996) \\
\hline $\mathrm{Ab}_{38} \mathrm{Qz}_{28} \mathrm{Or}_{34}$ & 2000 & 1100 & 10.0 & 90 & 5.41 & Holtz et al. (1992) \\
\hline $\mathrm{Ab}_{29} \mathrm{Qz}_{46} \mathrm{Or}_{25}$ & 2000 & 1100 & - & - & 5.12 & extrapolated from Holtz et al. (1992) \\
\hline Ab50Or50 & 5000 & 1100 & 10.3 & 70 & 10.61 & this study \\
\hline $\mathrm{Ab}_{38} \mathrm{Qz}_{28} \mathrm{Or}_{34}$ & 5000 & 1100 & 20.3 & 100 & 10.84 & Holtz et al. (1995) \\
\hline $\mathrm{Ab}_{29} \mathrm{Qz}_{46} \mathrm{Or}_{25}$ & 5000 & 1100 & - & - & 10.30 & extrapolated from Holtz et al. (1995) \\
\hline
\end{tabular}




\section{DISCUSSION}

\section{Pressure and temperature dependence of water solubility}

The effects of pressure and temperature on water solubility in silica melts are shown in Figure 1. The slope of the curve varies with $P$, and the data obtained at $1200^{\circ} \mathrm{C}$ suggest a point of inflection between 300 and $350 \mathrm{MPa}$. At $P<300 \mathrm{MPa}$, water solubility increases with increasing pressure faster than at $P>300 \mathrm{MPa}$. This behavior is also observed for feldspathic and quartzofeldspathic compositions (see Behrens 1995 and Holtz et al. 1995). In silica melts at $P>400 \mathrm{MPa}$, the rate of increase of water solubility with increasing $P$ becomes more pronounced. This is not observed in albite melts (Fig. 1), and can be attributed to the low pressure at which the upper critical point is attained in the system $\mathrm{SiO}_{2}-\mathrm{H}_{2} \mathrm{O}$ (Kennedy et al. 1962). At $P \leq 250 \mathrm{MPa}$, the effect of temperature was found to be negligible within experimental and analytical uncertainty. A positive correlation of water solubility with $T$ exists at $P>250$ $\mathrm{MPa}$ (at $400 \mathrm{MPa}$, water solubility increases by approximately $3 \cdot 10^{-3} \mathrm{wt} \% \mathrm{H}_{2} \mathrm{O}$ per $\left.1^{\circ} \mathrm{C}\right)$.

The water solubility data show that the incorporation mechanisms of water in silica melts are different at high and low water contents (Fig. 1). In the pressure range where water solubility is low (i.e., when mainly hydroxyls are incorporated in the melt), water solubility is only slightly affected by changing $T$ (at a given $P$ ). In contrast, at a high-water content of the melt (high $P$ ) , there is a small but significant positive dependence of water solubility on $T$. A positive temperature dependence of water solubility is also observed at high pressure (500 MPa) in feldspar and quartzofeldspathic melts. At such pressures, significant amounts of molecular water (in addition to hydroxyls) are incorporated into both silica and feldspar melts (e.g., Farnan et al. 1987; Stolper 1982; Nowak and Behrens 1995), leading to the conclusion that the temperature dependence of water solubility is positive when a high proportion of water is dissolved as molecular water in the melts. In contrast, when the dominant species are hydroxyls, the temperature dependence of water solubility is negative (see data of Holtz et al. 1995 and Behrens et al., unpublished manuscript, for 50 and $100 \mathrm{MPa}$ ).

\section{Compositional dependence of water solubility and implications}

Feldspar melts are known to have higher water solubilities than silica melts at a given $P$ and $T$. Comparing the solubility of water in silica and albite melts (at 1200 and $1100{ }^{\circ} \mathrm{C}$, respectively) in the range 100-500 $\mathrm{MPa}$ shows that water solubility in silica melts, expressed as $\mathrm{mol} \% \mathrm{H}_{2} \mathrm{O}$ on an eight oxygen basis, is approximately $33 \%$ lower than that in albite melts (Fig. 1).

The water solubility data can also be used to deduce mechanisms of water dissolution in silica-alkali feldspar melts. In this study, water solubility data was obtained for albite-silica melts at $200 \mathrm{MPa}$ (Table 2). Water solubility data for Ab-Or$\mathrm{H}_{2} \mathrm{O}$ and $\mathrm{Ab}-\mathrm{Or}-\mathrm{Qz}-\mathrm{H}_{2} \mathrm{O}$ melts are also available for 200 and $500 \mathrm{MPa}$ from Holtz et al. (1992, 1995), Behrens (1995), and Romano et al. (1996). These data show that water solubility varies nonlinearly with $P$ for compositions along silica-alkali feldspar joins (see Figs. 2 and 3 for compositions along the joins Qz-Ab and Qz- $\mathrm{Ab}_{50} \mathrm{Or}_{50}$, respectively). Only small varia- tions of water solubility are observed for feldspar-rich melts. Decreases in water solubility with increasing Qz content are more pronounced for compositions containing less than 50 mol\% feldspar. For Qz-Ab melts at $200 \mathrm{MPa}$, the data suggest a linear decrease of water solubility with decreasing $\mathrm{NaAlSi}_{3} \mathrm{O}_{8}$ content from 100 to $50 \mathrm{~mol} \%$. Water solubility starts to decrease significantly with increasing Qz content for compositions containing more than $75 \mathrm{~mol} \% \mathrm{Si}_{4} \mathrm{O}_{8}$. For compositions along the join $\mathrm{Qz}-\mathrm{Ab}_{50} \mathrm{Or}_{50}$, a linear decrease of water solubility with decreasing feldspar content from 100 to $50 \mathrm{~mol} \%$ is observed at 200 and $500 \mathrm{MPa}$ (Fig. 3).

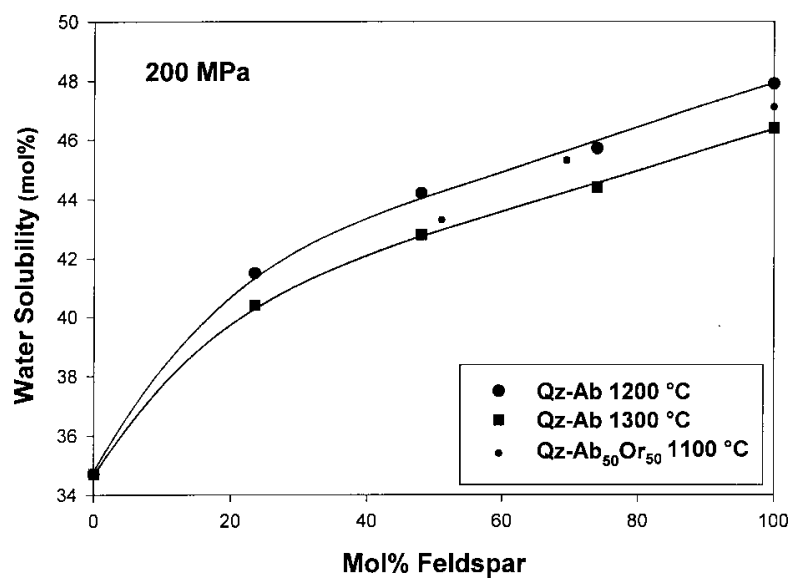

FIGURE 2. Effect of the anhydrous composition of quartzofeldspathic melts on water solubility at $200 \mathrm{MPa}$. The mole proportion of feldspar component in the anhydrous composition and the water solubility (given in $\mathrm{mol} \% \mathrm{H}_{2} \mathrm{O}$ ) are calculated on the basis of eight oxygen atoms $/ \mathrm{mol}$ silicate. The two water solubility curves are for $\mathrm{Si}_{4} \mathrm{O}_{8}-\mathrm{NaAlSi}_{3} \mathrm{O}_{8}(\mathrm{Qz}-$ $\mathrm{Ab}$ ) melts at 1200 and $1300{ }^{\circ} \mathrm{C}$. Small dots represent data along the compositional join $\mathrm{Si}_{4} \mathrm{O}_{8}-\left(\mathrm{Na}_{0.5} \mathrm{~K}_{0.5}\right) \mathrm{AlSi}_{3} \mathrm{O}_{8}$ (composition $\mathrm{Qz}-\mathrm{Ab}_{50} \mathrm{Or}_{50}$ in the text). The relevant analytical data are given in Tables 1 and 2.

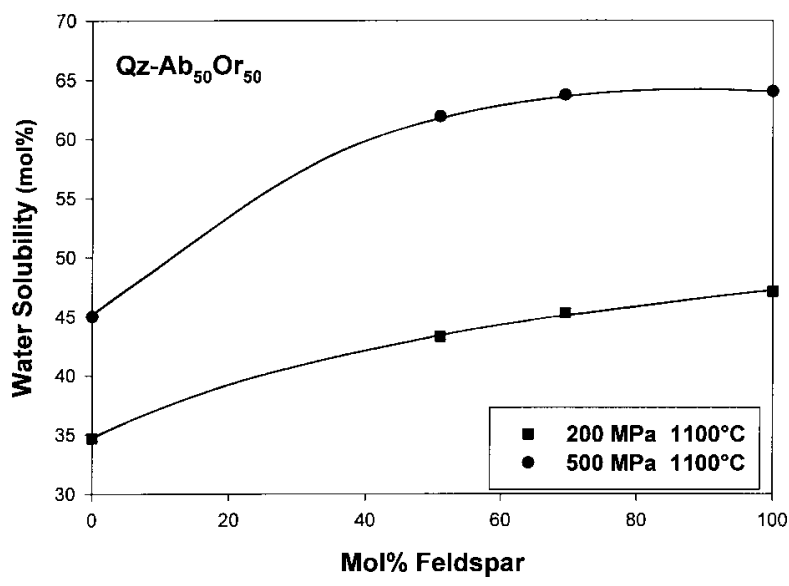

FIGURE 3. Effect of the anhydrous composition of melts along the join $\mathrm{Si}_{4} \mathrm{O}_{8}-\left(\mathrm{Na}_{0.5} \mathrm{~K}_{0.5}\right) \mathrm{AlSi}_{3} \mathrm{O}_{8}$ on water solubility at 200 and $500 \mathrm{MPa}$. The mole proportion of feldspar component in the anhydrous composition and the water solubility (given in $\mathrm{mol} \% \mathrm{H}_{2} \mathrm{O}$ ) are calculated on the basis of eight oxygen atoms/mol silicate. Data sources: Holtz et al. 1992, 1995; Romano et al. 1996; this study. 
The results of this study can be compared with predictions of the water solubility model of Burnham $(1979,1981)$ and Burnham and Nekvasil (1986). The main observation is that the linear decrease of water solubility (expressed as $\mathrm{mol} \%$ ) with increasing Qz content along the Qz-Ab join, predicted by the thermodynamic model, is incorrect for compositions with high Qz contents (the calculated linear variation of water solubility with Qz content results from the linear change of the Henry's law analog constant as a function of composition, see Holloway and Blank 1994, p. 194-195). The greater solubility of water in feldspar melts than in silica melts suggests that water is preferentially incorporated in melts that contain charge-balancing cations (alkalies). Comparison of water solubilities in pure silica and albite melts suggests that the structural units observed in silica glasses that are composed of corner-sharing $\mathrm{SiO}_{4}$ tetrahedra (e.g., Konnert et al. 1982; Elliot 1991) can cause a significant decrease in water solubility. Our results suggest that such Na-free structural units only exist in compositions containing between 0 and $50 \mathrm{~mol} \% \mathrm{NaAlSi}_{3} \mathrm{O}_{8}$. It is therefore concluded that variations in water solubility along silica-alkali feldspar joins are probably attributable to two different incorporation mechanisms of water. One mechanism is that prevailing in feldspar melts. In the incorporation model for these compositions proposed by Kohn et al. $(1989,1998)$, water associates with the alkalies to form hydrated Na complexes. The second water solubility mechanism is the same one proposed for silica melts; i.e., depolymerization of the melt and formation of Si-OH bonds (e.g., Stolen and Walrafen 1976; Mysen and Virgo 1986; Farnan et al. 1987). For compositions with albite contents lower than $50 \mathrm{~mol} \%$, an interplay between the $\mathrm{NaAlSi} \mathrm{O}_{8}-\mathrm{H}_{2} \mathrm{O}$ mechanism and the $\mathrm{SiO}_{2}-\mathrm{H}_{2} \mathrm{O}$ mechanism may control water solubility. The possible existence of two watersolubility mechanisms in such compositions has also been proposed by Schmidt et al. (2000) on the basis of NMR evidence. If the investigated compositions are extrapolated to granitic and rhyolitic melts, the results of this study suggest that the $\mathrm{NaAlSi}_{3} \mathrm{O}_{8}-\mathrm{H}_{2} \mathrm{O}$ mechanism predominates in such melts in the pressure range 200-500 MPa. Thus, a complex interaction between two water incorporation mechanisms probably does not need to be considered to model water solubility in natural felsic systems.

\section{ACKNOWLEDGMENTS}

This work was supported by Procope (project 96019) and by the EEC TMR network in situ melt properties (project no. ERB FM RX CT 960063 ). Reviews by J.G. Blencoe and an anonymous reviewer helped us improve this paper.

\section{REFERENCES CITED}

Becker, A., Holtz, F., and Johannes, W. (1998) Liquidus temperatures and phase compositions in the system Qz-Ab-Or at 5 kbar and very low water contents. Contributions to Mineralogy and Petrology, 130, 213-224.

Behrens, H. (1995) Determination of water solubilities in high-viscosity melts: an experimental study on $\mathrm{NaAlSi}_{3} \mathrm{O}_{8}$ and $\mathrm{KAlSi}_{3} \mathrm{O}_{8}$ melts. European Journal of Mineralogy, 7, 905-920.

Boettcher, A.L. (1984) the system $\mathrm{SiO}_{2}-\mathrm{H}_{2} \mathrm{O}-\mathrm{CO}_{2}$ : melting, solubility mechanisms of carbon, and liquid structure to high pressures. American Mineralogist, 69 , 823-833.

Burnham, C.W. (1979) The importance of volatile constituents. In H.S. Yoder, Ed., The evolution of the igneous rocks, p. 439-482. Princeton University Press, New Jersey.

(1981) The nature of multicomponent aluminosilicate melts. Physics and Chemistry of the Earth, 13-14, 197-229.
Burnham, C.W., and Nekvasil, H. (1986) Equilibrium properties of granite pegmatite magmas. American Mineralogist, 71, 239-263.

Elliot, S.R. (1991) Medium-range structural order in covalent amorphous solids. Nature, 354, 445-452.

Farnan, I., Kohn, S.C., and Dupree, R. (1987) A study of the structural role of water in hydrous silica glass using cross-polarisation magic angle spinning NMR. Geochimica et Cosmochimica Acta, 51, 2869-2873.

Holloway, J.R., and Blank, J.G. (1994) Application of experimental results to C-O$\mathrm{H}$ species in natural melts. In Mineralogical Society of America Reviews in Mineralogy, 30, 187-230.

Holtz, F., Behrens, H., Dingwell, D.B., and Taylor, R.P. (1992) Water solubility in aluminosilicate melts of haplogranitic composition at 2 kbar. Chemical Geology, 96, 289-302.

Holtz, F., Behrens, H., Dingwell, D.B., and Johannes, W. (1995) $\mathrm{H}_{2} \mathrm{O}$ solubility in haplogranitic melts: compositional, pressure, and temperature dependence. American Mineralogist, 80, 94-108.

Holtz, F., Roux, J., Ohlhorst, S., Behrens, H., and Schulze, F. (1999) The effects of silica and water on the viscosity of hydrous quartzofeldspathic melts. American Mineralogist, 84, 27-36.

Kennedy, G.C., Wasserburg, G.J., Heard, H.C., and Newton, R.C. (1962) The upper three-phase region in the system $\mathrm{SiO}_{2}-\mathrm{H}_{2} \mathrm{O}$. American Journal of Science, 260, 501-521.

Kohn, S.C., Dupree, R., and Smith, M.E. (1989) Proton environments and hydrogen-bonding in hydrous silicate glasses from proton NMR. Nature, 337, 539541.

Kohn, S.C., Smith, M.E., Dirken, P.J., van Eck, E.R.H., Kentgens, A.P.M., and Dupree, R. (1998) Sodium environments in dry and hydrous albite glasses: improved $1 \mathrm{H}$ solid state NMR data and their implications for water dissolution mechanisms. Geochimica et Cosmochimica Acta, 62, 79-87.

Konnert, J., D'Antonio, P., and Karle, J. (1982) Comparison of radial distribution function for silica glass with those for various bonding topologies. Journal of Non-Crystalline Solids, 53, 135-141.

Mysen, B.O. and Virgo, D. (1986) Volatiles in silicate melts at high pressure and temperature. 1. Interaction between $\mathrm{OH}$ groups and $\mathrm{Si}^{4+}, \mathrm{Al}^{3+}, \mathrm{Ca}^{2+}, \mathrm{Na}^{+}$and $\mathrm{H}^{+}$. Chemical Geology, 57, 303-331.

Nowak, M. and Behrens, H. (1995) The speciation of water in granitic glasses and melts determined by in situ near-infrared spectroscopy. Geochimica et Cosmochimica Acta, 59, 3445-3450.

Ostrovskiy, I.A., Mishina, G.P., and Povilaitis, V.M. (1959) Pressure-temperature projection of the system silica-water. Doklady Akademii Nauk SSSR, 126, 587588.

Oxtoby, S., and Hamilton, D.L. (1978a) The discrete association of water with $\mathrm{Na}_{2} \mathrm{O}$ and $\mathrm{SiO}_{2}$ in $\mathrm{NaAl}$ silicate melts. Contributions to Mineralogy and Petrology, $66,185-188$.

(1978b) Calculation of the solubility of water in granitic melts. In W.S. McKenzie, Ed., Progress in experimental petrology,. Natural Environmental Research Council Publications Series D, no. 11, p. 37-40. Department of Geology, Manchester University, Manchester, U.K.

Pichavant, M., Holtz, F., and McMillan, P. (1992) Phase relations and compositional dependence of $\mathrm{H}_{2} \mathrm{O}$ solubility in quartz-feldspar melts. Chemical Geology, 96, 303-320.

Romano, C., Dingwell, D.B., Behrens, H., and Dolfi, D. (1996) Compositional dependence of $\mathrm{H}_{2} \mathrm{O}$ solubility along the joins $\mathrm{NaAlSi}_{3} \mathrm{O}_{8}-\mathrm{KAlSi}_{3} \mathrm{O}_{8}, \mathrm{NaAlSi}_{3} \mathrm{O}_{8}$ $\mathrm{LiAlSi}_{3} \mathrm{O}_{8}$, and $\mathrm{KAlSi}_{3} \mathrm{O}_{8}-\mathrm{LiAlSi}_{3} \mathrm{O}_{8}$. American Mineralogist, 81, 452-461.

Roux, J., Holtz, F., Lefèvre, A., and Schulze, F. (1994) A reliable high-temperature setup for internally heated pressure vessels: applications to silicate melt studies. American Mineralogist, 79, 1145-1149.

Schmidt, B.C., Riemer, T., Kohn, S.C., Behrens, H., and Dupree, R. (2000) Different water solubility mechanisms in hydrous glasses along the Qz-Ab join. Evidence from NMR spectroscopy. Geochimica et Cosmochimica Acta, in press.

Silver, L.A. and Stolper, E.M. (1989) Water in albitic glasses. Journal of Petrology, $30,667-710$.

Stewart, D.B. (1967) Four-phase curve in the system $\mathrm{CaAl}_{2}-\mathrm{Si}_{2} \mathrm{O}_{8}-\mathrm{SiO}_{2}-\mathrm{H}_{2} \mathrm{O}$ between 1 and 10 kilobars. Schweizerische Mineralogische und Petrographische Mitteilungen, 47/1, 35-59.

Stolen, R.H. and Walrafen, G.E. (1976) Water and its relation to broken bond defects in fused silica. Journal of Chemistry and Physics, 64, 2623-2631.

Stolper, E. (1982) Water in silicate glasses. an infrared spectroscopic study. Contributions to Mineralogy and Petrology, 81, 1-17.

Sykes, D. and Kubicki, J.D. (1993) A model for $\mathrm{H}_{2} \mathrm{O}$ solubility mechanisms in albite melts from infrared spectroscopy and molecular orbital calculations. Geochimica et Cosmochimica Acta, 57, 1039-1052.

MANUSCRIPT RECEIVED NOVEMBER 3, 1998

MANUSCRIPT ACCEPTED DECEMBER 30, 1999

PAPER HANDLED BY JAMES G. BLENCOE 